\title{
REFINEMENTS OF SOME MAJORIZATION TYPE INEQUALITIES
}

\author{
M. Adil Khan, Sadia Khalid And J. PEČArić
}

Abstract. In this paper, we prove refinements of some companion inequalities to the Jensen inequality, namely Slater's inequality and the inequalities obtained by Matić and Pečarić (2000). We also give refinements of majorization type inequalities, generalized weighted Favard and Berwald inequalities.

Mathematics subject classification (2010): Primary 26D15.

Keywords and phrases: Convex functions, Jensen's inequality, Slater's inequality, majorization inequality, Favard and Berwald inequalities.

\section{REFERENCES}

[1] M. Adil Khan, M. Anwar, J. JakŠEtić And J. PeČArić, On some improvements of the Jensen inequality with some applications, J. Inequal. and Appl. 2009 (2009), Article ID 323615, 15 pages.

[2] M. ADIL KHAN AND J. PEČARIĆ, Improvement and reversion of Slater's inequality and related results, J. Inequal. and Appl. 2010 (2010), Article ID 646034, 14 pages.

[3] M. AdIL KHAN AND J. PeČARIĆ, On Slater's integral inequality, J. Math. Inequal. 5, 2 (2011), 231241.

[4] N. S. Barnett, P. Cerone And S. S. Dragomir, Majorisation inequalities for Stieltjes integrals, Appl. Math. Lett. 22 (2009), 416-421.

[5] L. BERWALD, Verallgemeinerung eines Mittelwertsatzes von J. Favard für positive konkave Funktionen (German), Acta Math. 79 (1947), 17-37.

[6] S. S. DRAGOMiR And C. J. GoH, A counter part of Jensen's discrrete inequality for differntiable convex mapping and applications in information theory, Math. Comput. Modelling 24, 2 (1996), 1-11.

[7] S. S. Dragomir, Some majorisation type discrete inequalities for convex functions, Math. Inequal. Appl. 7, 2 (2004), 207-216.

[8] J. FavaRD, Sur les valeures moyennes, Bull. Sci. Math. 57 (1993), 54-64.

[9] S. Hussain AND J. PEČARIĆ, An improvement of Jensen's inequality with some applications, Asian European Journal of Mathematics 2, 1 (2009), 85-94.

[10] S. Karlin And W.J. STUdDen, Tchebycheff Systems: with Applications in Analysis and Statistics, Interscience, New York, 1966.

[11] N. Latif, J. PeČArić, I. Perić, On majorization, Favard and Berwald inequalities, Ann. Funct. Anal. 2 (2011), 31-50.

[12] N. Latif, J. PeČArić, I. Perić, On discrete Favard's and Berwald's inequalities, Commun. Math. Anal. 12, 2 (2012), pp. 34-57.

[13] A. W. Marshall, I. OlKin And BarRy C. ARnold, Inequalities: Theory of Majorization and Its Applications (Second Edition), Springer Series in Statistics, New York 2011.

[14] L. Maligranda, J. PeČArić and L. E. Persson, Weighted Favard and Berwarld inequalities, J. Math. Anal. Appl. 190 (1995), 248-262.

[15] M. MatiĆ AND J. PeČARIĆ, Some companion inequalities to Jensen's inequalities, Math. Inequal. and Appl. 3, 3 (2000), 355-368.

[16] C. P. Niculescu And L. E. Persson, Convex Functions and their applications. A contemporary Approach, CMS Books in Mathematics 23, Springer-Verlag, New York, 2006.

[17] J. PEČARIĆ, O jednoj nejednakosti L. Berwalda i nekim primjenama, ANU BIH Radovi, Cdj. Pr. Mat. Nauka 74, 123-128. 
[18] J. PeČARIĆ, Multidimensional generalization of Slater's inequality, J. Approx. Theory 44 (1985b), 292-294.

[19] J. PeČArić And L. E. Persson, Some weighted multidimensional Berwald, Thunsdorff and Borell inequalities, Math. Panonica 7, 2 (1996), 281-290.

[20] J. PeČarić And S. Abramovich, On new majorization theorems, Rocky Mountain J. Math. 27, 3 (1997), 903-911.

[21] A. W. Roberts and D. E. Varberg, Convex functions, Academic Press, New York, 1973.

[22] M. L. Slater, A companion inequality to Jensen's inequality, J. Approx. Theory 32 (1981), 160-166. 